\title{
USABILITY ASSESSMENT OF INTERNATIONAL OFFICE WEBSITE OF DIPONEGORO UNIVERSITY WITH SCENARIO - BASED USABILITY EVALUATION METHOD AND WAMMI METHOD
}

\author{
Ratna Purwaningsih; Ikhsan Yenifi \\ Program Studi Teknik Industri, Fakutas Teknik Universitas Diponegoro \\ Jl. Prof. Soedarto, SH Tembalang, Semarang, 50239 \\ ratna.tiundip@gmail.com, ikhsan.yenifi@gmail.com
}

\begin{abstract}
Website development needs to pay attention to usability aspect which consist of four factors: efficiency, effectiveness, satisfactions and error rate. The website of International Office of Diponegoro University provides academic information for Indonesian students and foreign students. The website still has some problem, especially on searching certain information. This research aims to evaluate the design of the existing website and measures the usability. A well-designed website will help users to meet theirs needs and purposes. The methods used in this study are Scenario-Based End-User Evaluation and WAMMI (Website Analysis and Measurement Inventory). Users perform a number of task on the existing website and on the redesigned website and then provide feedback for each task they have done and fill a WAMMI questionnaire as a test of memorability. This questionnaire used to test users' memory on access process of a page from the site. The results of the data processing of usability test show that redesigned website has better value than existing website on effectiveness, efficiency, memorability and error rate.
\end{abstract}

Keywords: website design, usability, user centered design, WAMMI, scenario-based end user

\begin{abstract}
ABSTRAK
Pengembangan website perlu memperhatikan aspek usability yang terdiri atas faktor efficiency, effectiveness, dan satisfaction. Website International Office Universitas Diponegoro memberikan informasi akademik bagi mahasiswa Indonesia dan mahasiswa asing. Website masih memiliki beberapa masalah dalam mengakses informasi tertentu yang dibutuhkan. Penelitian ini bertujuan untuk mengevaluasi desain website dan melakukan pengukuran usabilitas. Adapun metode yang digunakan adalah Scenario-Based End User Evaluation dan WAMMI (Website Analysis and Measurement Inventory). User akan melakukan sejumlah tugas pada website awal dan website hasil perbaikan serta memberikan feedback untuk tiap task, lalu mengisi lembar kuesioner WAMMI serta melakukan uji memorability untuk mengetahui sejauh mana user dapat mengingat proses dalam mengakses suatu halaman dalam website. Hasil pengolahan data kuesioner usability test menunjukkan bahwa nilai usability dari website hasil rancangan lebih baik dari website sebelumnya dalam aspek efektivitas, efisiensi, memorability dan menurunnya error rate user.
\end{abstract}

Kata kunci: website design, usability, user centered design, WAMMI, scenario-based end user 


\section{PENDAHULUAN}

Setiap organisasi kini mengembangkan website yang bertujuan untuk menarik dan memudahkan para pengguna internet dalam mencari dan mendapatkan informasi yang berhubungan dengan organisasi tersebut. International Office Universitas Diponegoro (UNDIP) didirikan berdasarkan arahan Ditjen DIKTI agar setiap Universitas Negeri memiliki International Office untuk mengurusi kegiatan-kegiatan yang bersifat international. International Office UNDIP bertugas untuk memfasilitasi mahasiswa asing yang belajar di UNDIP seperti memberikan kesempatan exchange bagi mahasiswa UNDIP, memberikan informasi event international yang dapat diikuti mahasiswa UNDIP, mengadakan kerjasama dengan Universitas-universitas di luar negeri, dll. Saat ini terdapat 24 mahasiswa UNDIP yang melakukan exchange program yang difasilitasi oleh International Office UNDIP. Selain itu, banyak mahasiswa asing yang mendaftar serta melakukan studi di Universitas Diponegoro setiap tahunnya. Keberadaan website International Office menjadi sangat penting mengingat banyaknya jumlah mahasiswa asing yang kuliah di Universitas Diponegoro dan mahasiswa asal Indonesia yang melakukan exchange program. Selain itu, website International Office UNDIP dapat menarik minat mahasiswa, donator, tenaga kerja, bahkan universitas dari luar negeri untuk melakukan studi, pengajaran, bahkan bekerjasama dengan UNDIP.

Pada perancangan website, hal pertama yang perlu dilakukan adalah menentukan tujuan dan target pengguna (Campbell, 2014). Dengan mengetahui target pengguna maka rancangan halaman website diharapkan sesuai dengan kebutuhan dan keinginan pengguna (Sklar, 2009). Merancang website juga perlu memperhatikan fitur-fitur usability (Pearrow, 2000). Dari studi pendahuluan terhadap 31 mahasiswa Indonesia dan 13 mahasiswa asing dalam kuesioner pendahuluan mengenai frekuensi penggunaan website International Office diperoleh data bahwa $85 \%$ pengguna telah menggunakan website sebanyak kurang dari 5 kali dalam seminggu, 12\% pengguna menggunakan website sebanyak 5 - 10 kali dalam seminggu, dan $3 \%$ pengguna menggunakan website lebih dari 10 kali dalam seminggu. Juga ditemukan beberapa permasalahan dalam penggunaan website yaitu masih ada beberapa konten yang dibutuhkan namun belum tersedia dan konten yang belum dimanfaatkan secara maksimal seperti info exchange, scholarship information, search, daftar alumni mahasiswa, event information, dll.

Rumusan masalah penelitian ini adalah untuk melakukan perbaikan terhadap rancangan tampilan website dan melakukan perbandingan terhadap rancangan website sebelum dan sesudah dirancang ulang. Sedangkan tujuan penelitian adalah untuk mengidentifikasi permasalahan dan kebutuhan pengguna dalam menggunakan website International Office, melakukan usability test pada web international office UNDIP berdasarkan ISO 9241-11, melakukan perbaikan website International Office of UNDIP yang berhubungan dengan interface information dan kebutuhan pengguna, dan membandingkan usability desain awal dan alternatif website international office. Perancangan ulang interface website berdasarkan kebutuhan pengguna akan bermanfaat untuk memudahkan pengguna dalam mengoperasikan website dan mendapatkan informasi sesuai kebutuhan pengguna. Penilaian usability website berguna untuk melakukan perbandingan tingkat usability antara website sebelumnya dengan website hasil rancang ulang.

Powell (2000) menjelaskan perancangan website merupakan pendekatan multidisiplin yang berkaitan dengan perencanaan dan produksi web, tetapi tidak terbatas pada pengembangan teknis, struktur informasi, desain visual, dan pengiriman jaringan. Perancangan website adalah multi disiplin, maka sering untuk menarik ide-ide dan teori dari bidang ilmu yang berhubungan. Rosinski (2009) menyebutkan HCI memiliki signifikan focus pada tugas pre-design dan post-design berorientasi pada pengguna yaitu user requirements gathering, prototyping dan usability testing. Maka, usability testing adalah bagian yang penting setelah perancangan website. Hal senada juga disampaikan Hewett et. al. (2009) dalam ACM SIGCHI Curricula for Human-Computer Interaction mejelaskan bahwa Human- 
Computer Interaction merupakan sebuah disiplin ilmu yang berhubungan dengan desain, evaluasi, dan iplementasi sistem computer interaktif bagi manusia dan studi mengenai fenomane yang umum terjadi di sekitarnya.

Berdasarkan ISO 9241-11 seperti yang dikutip Umar dan Tatari (2008) menjelaskan usability merupakan pengembangan dari sebuah produk yang dapat digunakan oleh pengguna tertentu untuk mencapai tujuannya dengan efektif, efisien dan puas dalam lingkup penggunaan tertentu. ISO/IEC 9126-1 menjelaskan bahwa usability merupakan kemampuan sebuah produk software untuk dipahami, dipelajari, digunakan dan menarik pengguna ketika digunakan dalam keadaan tertentu. Sedangkan IEEE std.610.12 menyatakan usability adalah kemudahan di mana pengguna dapat belajar mengoperasikan, menyiapkan input dan menafsirkan output dari sebuah sistem atau komponen.

\section{METODE}

\section{Scenario-Based End User Evaluation}

Granic et. al. (2008) menjelaskan bahwa Scenario-Based End User Evaluation merupakan kombinasi antara pengukuran berbasis kebiasaan dan opini melibatkan pengguna dan scenario atau tugas tertentu untuk mengetahui usability terhadap pengguna, performa dan tingkat kepuasan, dan menstimulasi pola penggunaan sesungguhnya yang diharapkan.

Dalam melakukan Scenario-Based End User Evaluation, pengguna dihadapkan pada task yang mendekati kegiatan pada keadaan sebenarnya. Scenario-Based End User Testing dapat mengukur hal-hal sebagai berikut: (1) Walkthrough Usability Test. Tahap ini terdiri dari 2 bagian yaitu, pertama, penugasan scenario terpadu mengenai fungsi dasar sistem dan aspek utama interface dan kedua, penugasan spesifik tugas tertentu dimana pengguna melakukan tugasnya sendiri. Pengujian pada tahap ini dapat mengukur tiga atribut yaitu suitability, yaitu merupakan tingkat kecocokan sistem terhadap tugas yang akan dikerjakan, learnability, yaitu merupakan ukuran seberapa mudah pengguna untuk mempelajari sistem berapa cepat tugas dilakukan, dan error rate, yaitu rasio error ketika menggunakan sistem. (2) Memo Test. Tahap ini merupakan pengukuran ingatan mengenai tampilan interface dengan menjelaskan kepada pengguna akibat dari menuliskan perintah untuk operasi tertentu. (3) Usability Satisfaction questionnaire. Tahap ini merupakan pengukuran usability menggunakan suatu kuesioner.

Cara mengukur usability dan mengembangkan kuisionernya adalah didasarkan pada faktorfaktor usability dalam SUM (Single Usability Matrics). Model sumatif usability dapat dilihat dalam gambar 1 .

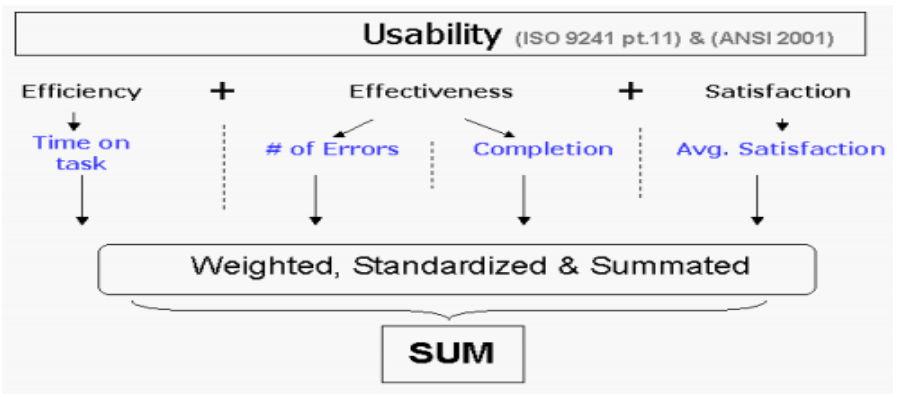

Gambar 1 Model Sumatif SUM (Sauro, 2005) 
SUM menurut Sauro (2005) merupakan metric tunggal, terstandarisasi dan dijumlahkan untuk merangkum informasi yang dominan dalam empat metric usability yang umum. Metric tersebut berdasarkan ANSI dan ISO 9241 adalah dimensi efektifitas, efisiensi, dan kepuasan. Seperti terlihat pada gambar 1, keempat metriks tersebut digunakan untuk mendapatkan sistem penilaian SUM dalam evaluasi sumatif berupa nilai penyelesaian tugas, jumlah rata-rata error, waktu rata-rata pengerjaan tugas, dan tingkat kepuasan.

Menurut Chiew dan Salim (2003) terdapat beberapa meotde dan alat yang dapat digunakan dalam mengevaluasi Usability suatu website yaitu WAMMI, NIST Web, Metrics, Bobby (software aksebilitas website) dan Protocol Analysis. Metode WAMMI menggunakan satu set kuesioner yang harus diisi oleh pengguna, kuesioner ini bertujuan menggali kebutuhan pengguna tentang konten apa sajakah yang harus disediakan dalam website dan kemudahan pengoperasiannya.

\section{WAMMI (Website Analysis and Measurement Inventory)}

Kirakowski (2013) menjelaskan WAMMI (Website Analysis and Measurement Inventory) merupakan layanan analisis website yang mengukur dan menganalisis pengalaman pengguna web untuk membantu pengguna dalam mencapai tujuannya. WAMMI secara iterative dikembangkan menggunakan teknik psikometrik dan terbukti secara ilmiah mempunyai rating data reliability antara 0,9 dan 0,93.WAMMI dikembangkan oleh Human Factors Research Group (HFRG) pada tahun 1999. Layanan WAMMI berkisar pada 20 pertanyaan kuesioner dan database internasional. Kuesioner WAMMI dinilai menggunakan lima pilihan dalam skala likert. Langkah-langkah melakukan WAMMI adalah pertama, melakukan pengujian berbasis skenario yaitu beberapa skenario tugas dalam menggunakan website International Office UNDIP disiapkan untuk dikerjakan oleh pengguna. Pengguna diminta melaksakanan skenario tugas, menjelaskan fungsi-fungsi tiap aspek dari interface, dan menjelaskan kembali langkah-langkah dalam melakukan tugas.

Kedua, penyebaran kuesioner WAMMI yaitu kuesioner WAMMI disusun ke dalam 20 pertanyaan. Penyebaran kuesioner WAMMI untuk mengetahui tingkat subjektif usability website kepada mahasiswa Indonesia maupun asing di UNDIP. Karena jumlah populasi pengguna website tidak diketahui secara pasti, kuesioner disebar dengan metode purposive sample sebanyak 30 orang karena mendekati distribusi normal. Ketiga, pengolahan data dan analisis yaitu pengolahan data dilakukan dengan menghtiung presentasi keberhasilan dan waktu yang dibutuhkan dalam melakukan tugas scenario dan tingkat kepuasan subjektif untuk tiap pertanyaan kuesioner WAMMI. Total bobot nilai kemudian akan dihitung rata-ratanya untuk usabilitas secara keseluruhan.

Keempat, membuat solusi design (Prototype) yaitu perancangan website dilakukan berdasarkan prinsip Research-based Web Design \& Usability Guidelines yang disusun oleh The U.S. Department of Health and Human Services (HHS) dengan U.S General Services Administration. Perancangan dibagi menjadi dua bagian yaitu perancangan prototype bayangan dan prototype mesin. Prototype Bayangan adalah tahapan yang merupakan perancangan dan pembangunan arsitektur informasi yang meliputi penentuan area konten website, pengorganisasioan area konten, membentuk pemetaan situs, penguraian struktur navigasi, penamaan konten, membuat wireframes. Prototype Mesin adalah Wireframes yang dirancang pada prototype bayangan kemudian diimplementasikan ke dalam bahasa HTML dan PHP. Kelima, evalusai desain yaitu Interface website yang telah dirancang kemudian diuji dengan pengujian usability. Metode yang dilakukan adalah metode Scenario-Based Usability Evaluation, penyebaran kuesioner WAMMI serta wawancara. Metode Scenario-Based Usability Evaluation dilakukan dengan melihat waktu penyelesaian suatu tugas, presentasi jumlah kesalahan, dan presentasi jumlah tugas yang selesai.

Kuesioner Wammi dilakukan untuk melihat tingkat usability. Wawancara dilakukan untuk mengetahui persepsi pengguna terhadap perancangan informasi yang telah dibangun. Hasil dari 
evaluasi interface design yang dirancang kemudian dibandingkan dengan interface design mula-mula. Evaluasi Desain menggunakan teknik pemilihan nonprobability sampling berupa purposive sampling karena jumlah populasi pengguna website UNDIP tidak diketahui dengan jumlah sampel minimum yang digunakan sebanyak 30 orang yang terdiri dari mahasiswa Indonesia dan Mahasiswa Asing UNDIP

\section{Pembuatan Wireframe}

Wireframe dibuat untuk menggambarkan alternative design dari website sebelum dibuat ke dalam prototype website. Wireframe dibuat berdasarkan berdasarkan input yang diberikan responden ketika meyelesaikan tasks pada evaluasi bebrbasis scenario. Wireframe juga dilakukan berdasarkan standar yang telah ditetapkan oleh tim webmaster UNDIP, Research-based Web Design \& Usability Guidelines, web content accessibility guidelines (WCAG), dan pedoman perancangan web oleh Campbell (2014).

Beberapa solusi redesign antara lain: (1) Pengelompokkan dan penempatan konten-konten yang sejenis di bawah header. (2) Penempatan slide pada halaman depan. (3) Pemberian kotak pencarian. (4) Penghapusan agenda dan pemberian kolom informasi event. (5) Pemisahan konten scholarship dan exchange program. (6) Penghilangan konten-konten yang dirasa tidak berguna. (7) Pemasangan media sosialpada bagian kanan homepage. (8) Perbaikan nama konten dan informasi di dalamnya.

Dalam perancangan prototype mesin, solusi redesain serta desain yang dibuat dalam wireframe diimplementasikan dalam bahasa HTML dan PHP.

\section{Indikator usability website}

Bogin (2007) menjelaskan HCI focus pada interaksi antara pengguna manusia dan sistem komputer termasuk didalamnya user interface dan process yang terjadi selama pengoperasian. Sejak akhir 1990, studi HCI menjadi lebih luas dan lebih memperhatikan pada pemahaman maksud dan tujuan pengguna, kemampuan personal, lingkungan sosial, dan desain interface tempat mereka berinteraksi. HCI juga mempelajari tentang proses pengembangan sistem interaktif dan manfaatnya bagi pengguna manusia.

Untuk menilai usability web sebagai ukuran performasi web dalam penggunaan oleh manusia, Rubin (2011) mengembangkan lima komponen Usability, yaitu: (1) Efficiency. Merupakan seberapa cepat tujuan pengguna dapat dicapai secara akurat dan lengkap dan biasanya diukur dalam satuan waktu. (2) Effectiveness. Merupakan seberapa jauh produk dapat memenuhi harapan pengguna dan seberapa mudah pengguna dapa menggunakannya sesuai tujuan mereka. (3) Learnability. Merupakan kemampuan pengguna untuk megoperasikan sistem ke dalam suatu tingkatan kompetensi setelah melakukan pelatihan dalam jangka waktu tertentu. (4) Satisfaction. Merupakan persepsi pengguna, perasaan, dan pendapat mengenai produk, didapat melalu pertanyaan oral maupun tertulis. Pengguna cenderung melakukan tugas dengan baik pada produk yang memenuhi kebutuhan dan memberikan kepuasan. Ukuran satisfaction dikembangkan dengan skala likert pada skala 1-5, hal ini juga dicontohkan oleh Bevan (2005). 


\section{HASIL DAN PEMBAHASAN}

\section{Evaluasi Pengguna Berbasis Skenario}

Smith \& Mayes (1996) menyatakan bahwa usability merupakan faktor vital dalam menentukan kesuksesan sebuah system computer baru atau layanan berbasis komputer. Berdasarkan Usability Professionals Association, usability merupakan pendekatan terhadap pengembangan produk yang memasukkan feedback dari pengguna melalui siklus pengembangan untuk megnurangi biaya dan menciptakan produk dan alat yang memenuhi kebutuhan pengguna. Evaluasi Pengguna Berbasis Skenario dilakukan untuk mengetahui penggunaan website International Office of UNDIP oleh sasaran pengguna yang terdiri dari mahasiswa Indonesia dan mahasiswa asing. Dalam melakukan Evaluasi Pengguna Berbasis Skenario, responden melakukan 6 tugas skenario untuk mengetahui tingkat suitability, learnability, error rate, memorability, serta satisfaction rate. Selain itu, pengguna dimintai saran sebagai feedback dalam membangun rancangan alternative desain website International Office UNDIP. Hasil dari evaluasi berbasis skenario untuk mahasiswa Indonesia dapat dilihat pada tabel 1 .

Tabel 1 Hasil Evaluasi Suitability dan Learnability Mahasiswa Indonesia

\begin{tabular}{|c|c|c|c|c|c|}
\hline \multirow{2}{*}{\multicolumn{2}{|c|}{ Suitability }} & $\begin{array}{l}\text { Effectiveness } \\
\text { measurement }\end{array}$ & $\begin{array}{c}\text { Efficiency } \\
\text { measurement (detik) }\end{array}$ & $\begin{array}{c}\text { Satisfaction } \\
\text { measurement }\end{array}$ & Error \\
\hline & & $57.78 \%$ & 46.12 & $16.11 \%$ & \\
\hline \multirow{6}{*}{ Learnability } & Task 1 & $26.67 \%$ & 0 & $1.36 \%$ & 56 \\
\hline & Task 2 & $100.00 \%$ & 60.67 & $94.84 \%$ & 3 \\
\hline & Task 3 & $70.00 \%$ & 46.39 & $62.17 \%$ & 19 \\
\hline & Task 4 & $66.67 \%$ & 97.67 & $24.51 \%$ & 36 \\
\hline & Task 5 & $23.33 \%$ & 68.50 & $3.36 \%$ & 50 \\
\hline & Task 6 & $60.00 \%$ & 51.53 & $44.43 \%$ & 18 \\
\hline
\end{tabular}

Tabel 1 menunjukkan bahwa ada 6 task yang harus dikerjakan responden untuk menilai efektivitas, efisiensi, kepuasan pengguna dalam mengoperasikan website dan tingkat kesalahan yang dilakukan pengguna. Tabel 1 adalah hasil pengukuran untuk website sebelum dilakukan perbaikan atau sebelum re design. Pada tabel 4.1 di atas, terdapat 4 task dengan keberhasilan di bawah $70 \%$, yaitu task 1 (pencarian informasi exchange), task 4 (pencarian beasiswa), task 5 (pencarian informasi internship), dan task 6 (pencarian informasi HNMUN). Berdasarkan HHS dan W3C (World Wide Web Consortium), hal ini karena penempatan menu tidak berada di bagian tengah atas. Selain itu, ukuran font yang kecil juga mepengaruhi dalam penyelesaian task. Sehingga dalam rancangan desain baru perlu adanya perbaikan pada penempatan menu di atas tengah dan perbaikan ukuran font.

Ukuran lainnya yang digunakan untuk menilai website ini adalah memorability, subjective satisfaction dan over all subjective satisfaction. Memorability didapatkan ketika pengguna menjawab pertanyaan-pertanyaan mengenai ingatan pengguna dalam mengoperasikan suatu task, seperti fungsi suatu konten atau langkah dalam mendapatkan suatu informasi. Subjective satisfaction didapatkan dengan cara menyebarkan kuesioner subjective, dalam hal ini adalah WAMMI. Overall Subjective Satisfaction Measurment didapatkan dengan menghitung rata-rata dari hasil pengukuran satisfaction yang ada. Jumlah error yang dilakukan pada setiap task digunakan dalam menghitung error rate. Untuk hasil error rate, memorability, dan subjective satisfaction dapat dilihat pada table 2. 
Tabel 2 Hasil Evaluasi Error Rate, Memorability, Subjective Satisfaction Mahasiswa Indonesia

\begin{tabular}{lccc}
\hline \multicolumn{1}{c}{ Aspek } & $\begin{array}{c}\text { Effectiveness } \\
\text { measurement }\end{array}$ & $\begin{array}{c}\text { Efficiency } \\
\text { measurement }\end{array}$ & $\begin{array}{c}\text { Satisfaction } \\
\text { measurement }\end{array}$ \\
\hline Error rate & $50.56 \%$ & $182 \mathrm{kali}$ & $12.10 \%$ \\
Memorability & $84.44 \%$ & $8.17 \mathrm{detik}$ & $87.90 \%$ \\
Subjective satisfaction & & & $25.78 \%$ \\
Overall subjective satisfaction measurement & & & $38.47 \%$ \\
\hline
\end{tabular}

Memorability diperoleh ketika pengguna menjawab pertanyaan-pertanyaan mengenai ingatan pengguna dalam mengoperasikan suatu task, seperti fungsi suatu konten atau langkah dalam mendapatkan suatu informasi. Subjective satisfaction didapatkan dengan menyebarkan kuesioner subjective, dalam hal ini adalah WAMMI. Overall Subjective Satisfaction Measurment didapatkan dengan menghitung rata-rata dari hasil pengukuran satisfaction yang ada.Evaluasi scenario juga dilakukan oleh mahasiswa asing untuk mengetahui effectiveness, efficiency dan satisfaction dalam menggunakan website International Office. Hasil evaluasi skenario untuk mahasiswa asing dapat dilihat pada tabel berikut.

Tabel 3 Hasil Evaluasi Suitability dan Learnability Mahasiswa Asing

\begin{tabular}{|c|c|c|c|c|c|}
\hline \multirow{2}{*}{\multicolumn{2}{|c|}{ Suitability }} & $\begin{array}{l}\text { Effectiveness } \\
\text { measurement }\end{array}$ & $\begin{array}{c}\text { Efficiency } \\
\text { measurement(detik) }\end{array}$ & $\begin{array}{c}\text { Satisfaction } \\
\text { measurement }\end{array}$ & Error \\
\hline & & $75 \%$ & 50.94 & $52.79 \%$ & \\
\hline \multirow{6}{*}{ Learnability } & Task 1 & $63 \%$ & 115.13 & $29.46 \%$ & 26 \\
\hline & Task 2 & $73 \%$ & 42.21 & $71.57 \%$ & 14 \\
\hline & Task 3 & $100 \%$ & 31.47 & $99.96 \%$ & 8 \\
\hline & Task 4 & $53 \%$ & 56.30 & $32.64 \%$ & 24 \\
\hline & Task 5 & $80 \%$ & 36.14 & $47.61 \%$ & 21 \\
\hline & Task 6 & $67 \%$ & 83.42 & $47.61 \%$ & 21 \\
\hline
\end{tabular}

Pada tabel 3 di atas, terdapat 3 task dengan keberhasilan di bawah $70 \%$, yaitu task 1 (pencarian informasi post graduate), task 4 (pencarian beasiswa darmasiswa), dan task 6 (pencarian informasi tropical course), dan task 3. Berdasarkan HHS dan W3C (World Wide Web Consortium), hal ini disebabkan karena terdapat inkonsistensi dalam penamaan menu. Selain itu, penempatan menu dan ukuran font yang kecil juga mepengaruhi dalam penyelesaian task.

Tabel 4 Hasil Evaluasi Error Rate, memorability dan Subjctive Satisvaction Mahasiswa Asing

\begin{tabular}{lccc}
\hline \multicolumn{1}{c}{ Aspek } & $\begin{array}{c}\text { Effectiveness } \\
\text { measurement }\end{array}$ & $\begin{array}{c}\text { Efficiency } \\
\text { measurement }\end{array}$ & $\begin{array}{c}\text { Satisfaction } \\
\text { measurement }\end{array}$ \\
\hline Error rate & $46 \%$ & 97 & $50.80 \%$ \\
Memorability & $69 \%$ & 14.27 & $33 \%$ \\
Subjective satisfaction & & & $60.64 \%$ \\
Overall subjective satisfaction measurement & & & $52.61 \%$ \\
\hline
\end{tabular}

Dari evaluasi terhadap desain existing web yang dilakukan baik pada mahasiswa Indonesia maupun asing, secara umum terdapat beberapa aspek yang belum memenuhi batas nilai baik pada indeks usability $(0,6)$, yaitu suitability, memorability, error rate, dan subjective satisfaction. Suitability menjelaskan mengenai kecocokan suatu web terhadap pengguna yang dinilai dari banyaknya tugas yang berhasil diselesaikan. Untuk meningkatkan suitability, maka perlu semua konten yang berkaitan 
dikelompokkan menjadi satu. Penempatan konten pun diletakkan di tempat yang mudah dilihat dan ditemukan dan juga penamaan menu konten sesuai dengan informasi yang dimilikinya. Untuk menurunkan error rate, maka selain peletakkan menu konten yang strategis, yaitu di bawah header, ukuran font perlu disesuakan agar pengguna dapat membaca dengan jelas. Dalam hal meningkatkan memorability, selain penamaan yang mudah diingat, perlu pemberian warna cerah pada website, dan juga memunculkan highlight ketikan menunjuk suatu menu. Apabila terdapat penambahan fasilitas dan kemudaha, maka satisfaction rate pengguna diharapkan meningkat.

\section{Evaluasi Hasil Usability Test Desain Alternatif}

Setelah pengolahan serta analisis data dilakukan. Langkah berikutnya adalah pembuatan solusi desain website International Office of UNDIP. Perancangan ulang dilakukan dengan menggunakan patoken webometrics, yaitu dengan melihat dari sisi visibility, presence, openness, dan excellence. Terdapat 3 langkah dalam meningkatkan peringkat webometrics, yaitu langkah langkah terkait kebijakan, teknik, dan content. Content merupakan langkah yang paling menentukan keberhasilan dari keseluruhan strategi, karena pada akhirnya content-lah yang dinilai pada proses perangkingan Webometrics.

Pada rancangan alternative design menampilkan menu konten yang lebih sedikit dibandingkan desain website sebelumnya. Beberapa subkonten yang memiliki sasaran yang sejenis dikelompokkan ke dalam satu menu konten seperti scholarship program dan exchange program. Selain itu, dalam rancangan alternative desain memunculkan subkonten yang baru seperti internship information serta menghilangkan subkonten yang tidak diperlukan seperti slide show. Wireframe desain alternative website International Office of UNDIP menggunakan model layout left index. Hal ini agar informasi dapat disajikan dengan baik di halaman utama dan mempermudah penyediaan menu atau navigasi.

Evaluasi alternative design dilakukan untuk mengetahui penggunaan alternative design oleh pengguna serta membandingkannya dengan penilaian desain lama. Evaluasi dilakukan dengan metode seperti ketika melakukan evaluasi desan pertama dengan 30 responden mahasiswa Indonesia serta 30 mahasiswa asing. Hasil dari evaluasi desain alternative untuk mahasiswa Indonesia diberikan pada tabel 5, sedangkan hasil dari evaluasi desain alternative untuk mahasiswa asing diberikan pada tabel 6 .

Tabel 5 Hasil Evaluasi Redesain Berbasis Skenario untuk Mahasiswa Indonesia

\begin{tabular}{|c|c|c|c|c|}
\hline \multirow{2}{*}{\multicolumn{2}{|c|}{ Suitability }} & $\begin{array}{l}\text { Effectiveness } \\
\text { measurement }\end{array}$ & $\begin{array}{c}\text { Efficiency } \\
\text { measurement }\end{array}$ & $\begin{array}{c}\text { Satisfaction } \\
\text { measurement }\end{array}$ \\
\hline & & $97.10 \%$ & 24.71 & $97.61 \%$ \\
\hline \multirow{5}{*}{ Learnability } & Task 2 & $100.00 \%$ & 17.75862 & $98.75 \%$ \\
\hline & Task 3 & $86.67 \%$ & 33.78261 & $82.12 \%$ \\
\hline & Task 4 & $96.67 \%$ & 34.15 & $93.32 \%$ \\
\hline & Task 5 & $100.00 \%$ & 21.16667 & $100.00 \%$ \\
\hline & Task 6 & $100.00 \%$ & 11.23333 & $99.00 \%$ \\
\hline Error rate & & $12.08 \%$ & 58 & $99.99 \%$ \\
\hline \multicolumn{2}{|l|}{ Memorability } & $94.44 \%$ & 8.790123 & $99.62 \%$ \\
\hline \multicolumn{2}{|c|}{ Subjective satisfaction } & & & $88.10 \%$ \\
\hline \multicolumn{2}{|c|}{ Overall subjective satisfaction } & & & $95.44 \%$ \\
\hline
\end{tabular}


Tabel 6 Hasil Evaluasi Redesain Berbasis Skenario untuk Mahasiswa Asing

\begin{tabular}{|c|c|c|c|c|}
\hline & & $\begin{array}{l}\text { Effectiveness } \\
\text { measurement }\end{array}$ & $\begin{array}{c}\text { Efficiency } \\
\text { measurement }\end{array}$ & $\begin{array}{c}\text { Satisfaction } \\
\text { measurement }\end{array}$ \\
\hline \multicolumn{2}{|c|}{ Suitability } & $100.00 \%$ & 31.73 & $99.99 \%$ \\
\hline \multirow{6}{*}{ Learnability } & Task 1 & $100.00 \%$ & 72.70 & $92.78 \%$ \\
\hline & Task 2 & $100.00 \%$ & 36.8 & $92.78 \%$ \\
\hline & Task 3 & $100.00 \%$ & 28.63 & $99.99 \%$ \\
\hline & Task 4 & $100.00 \%$ & 20.27 & $99.99 \%$ \\
\hline & Task 5 & $100.00 \%$ & 17.23 & $100.00 \%$ \\
\hline & Task 6 & $100.00 \%$ & 19.7 & $99.99 \%$ \\
\hline Error rate & & $14.89 \%$ & 67 & $99.99 \%$ \\
\hline \multicolumn{2}{|l|}{ Memorability } & $86.67 \%$ & 12.09 & $98.71 \%$ \\
\hline \multicolumn{2}{|c|}{ Subjective satisfaction } & & & $86.67 \%$ \\
\hline \multicolumn{2}{|c|}{ Overall subjective satisfaction } & & & $97.09 \%$ \\
\hline
\end{tabular}

\section{Efektifness dan Efficiency}

Efektifness atau efektivitas sebuah web diukur salah satunya dari kemudahan web untuk diingat. Menurut responden mahasiswa Indonesia, efektivitas desain lama adalah $55 \%$ dan web baru $97 \%$. Sedangkan menurut mahasiswa asing efektivitas web lama $75 \%$ dan web hasil redesain $100 \%$. Peningkatan yang paling besar terjadi pada pengguna mahasiswa Indonesia sebesar $42 \%$. Hal ini disebabkan beberapa pengguna banyak yang merasa kebingungan dengan banyaknya menu yang berbahasa Inggris yang muncul sekaligus. Selain itu, terdapat beberapa informasi yang tidak sesuai pada tempatnya ataupun yang sulit dicari. Namun, pada desain altenatif, penempatan menu yang berada di atas tengah halaman memudahkan pengguna dalam mencari menu dan informasi yang dibutuhkan. Penilaian efektivitas digambarkan dalam Gambar 2.

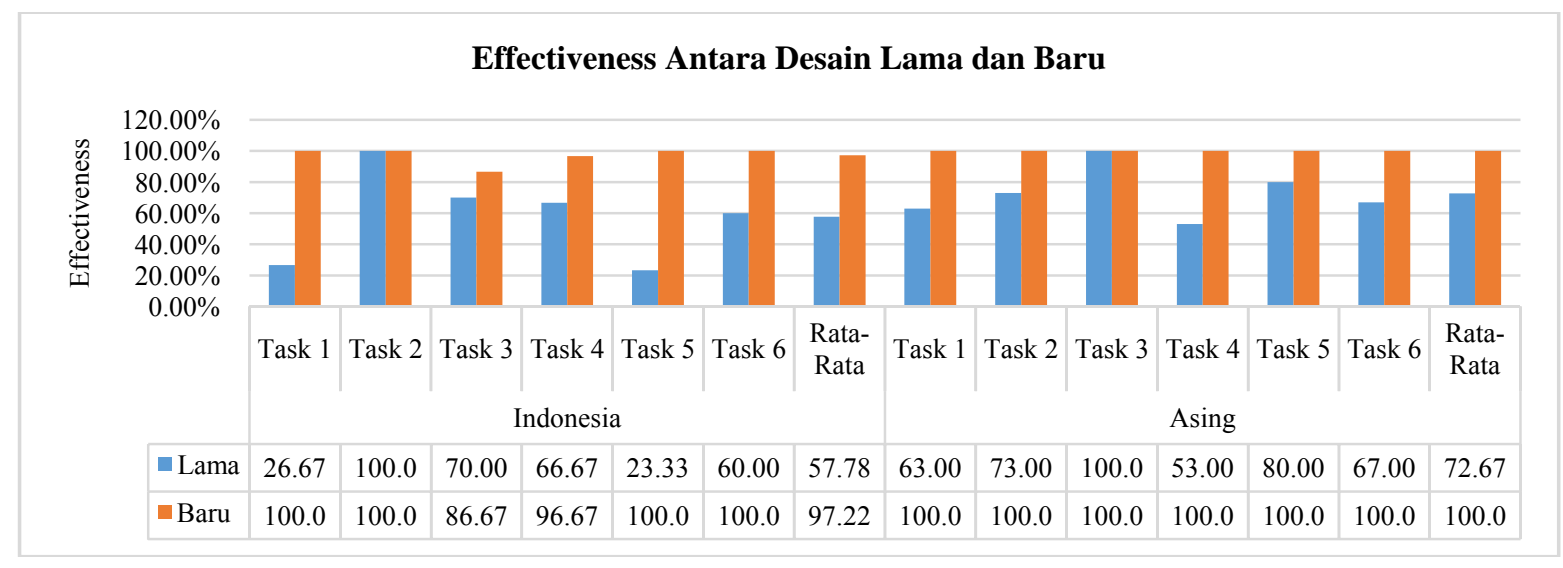

Gambar 2 Evaluasi Learnability Effectiveness Desain Lama dan Alternatif

Menurut gambar 2, pada alternative design terjadi peningkatan baik pada pengguna mahasiswa Indonesia maupun asing. Nilai efektifitas untuk mahasiswa Indonesia meningkat menjadi $97 \%$ dan mahasiswa asing menjadi 100\%. Sedangkan mahasiswa asing mengalami peningkatan menjadi $100 \%$ pada semua task. Hal ini dikarenakan pengguna asing dapat mencari informasi dengan mudah karena adanya horizontal drop-down menu dan konten maupun subkonten diletakkan pada menu for International student. 
Ukuran lainnya adalah Efficiency, salah satunya diukur dengan waktu yang dibutuhkan untuk menyelesaikan Task dan mengukur error rate. Ukuran efisiensi website lama menurut mahasiswa Indonesia adalah $25 \%$ dan web hasil redesain $46 \%$. Sedangkan menurut mahasiswa asing web lama $32 \%$ dan web hasil redesain $51 \%$. Peningkatan terjadi karena dengan adanya pengelompokan konten dan horizontal drop-down menu, pengguna tidak memerlukan banyak waktu untuk melakukan pencarian konten yang dituju. Selain itu, penempatan dan penampilan konten dan subkonten memudahkan pengguna untuk segera mendapatkan informasi yang diinginkan. Penilaian efisiensi diberikan pada Gambar 3.

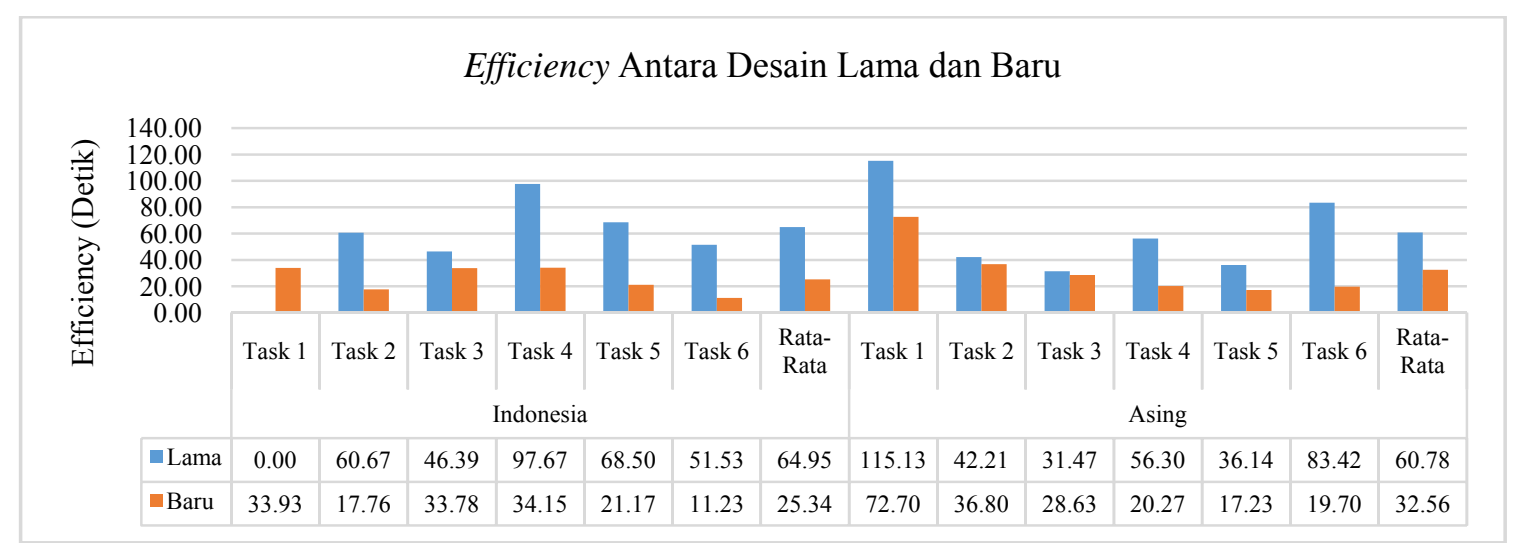

Gambar 3 Evaluasi Efficiency Desain Lama dan Desain Alternatif

Menurut Gambar 3, pada penggunaan alternative design terjadi penurunan tingkat penggunaan secara drastis hampir di seluruh task. Hal ini dikarenakan pengguna tidak memerlukan banyak waktu untuk menjelajah halaaman muka ataupun mempelajari website. Pada task 1 desain lama pada pengguna Indonesia, nilai efisiensi tidak dapat didefinisikan karena banyaknya pengguna yang tidak berhasil menemukan informasi dan pengguna yang berhasil memberikan nilai kepuasan di bawah 4 .

\section{Error Rate dan Memorability}

Tingkat error menjelaskan perbandingan jumlah kesalahan dengan jumlah kesempatan dalam melakukan kesalahan. Tingkat error dan memorability sebagai perbandingan antara desain lama dan baru diberikan pada Gambar 4.

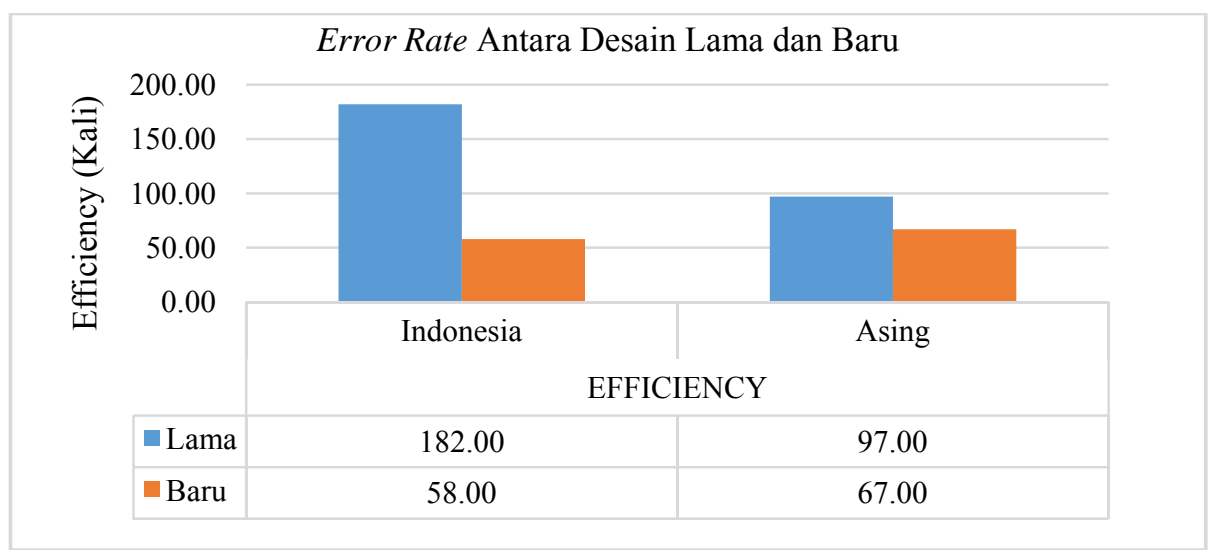

Gambar 4 Evaluasi Error Rate Efficiency Desain Lama dan Alternatif 
Dari Gambar 4 dapat dilihat bahwa dari nilai efektifitas untuk mahasiswa Indonesia aspek error rate sebesar $50 \%$ dari total 360 kali kesempatan dan mahasiswa asing aspek sebesar $46,19 \%$ dari total 210 kali kesempatan. Pada alternative design terjadi penurunan error rate baik pada pengguna mahasiswa Indonesia maupun asing. Tingkat error rate mengalami penurunan karena para pengguna merasa lebih mudah mencari informasi yang diinginkan. Namun, beberapa error masih terjadi pada alternative design. Hal ini disebabkan karena beberapa pengguna Indonesia salah memaknai menu dalam Bahasa Inggris. Sedangkan pada mahasiswa asing, masih terdapat keraguan dalam masuk sebuah konten.

Nilai efektifitas untuk mahasiswa Indonesia meningkat menjadi $12,08 \%$ dari 480 kali kesempatan dan mahasiswa asing menjadi $14,89 \%$ dari 450 kali kesempatan. Terdapat dua pengukuran memorability, yaitu memorability efficiency dan memorability efectiveness. Hasil pengukuran memorability efektivieness pada Gambar 5 dan memorability efficiency pada Gambar 6.

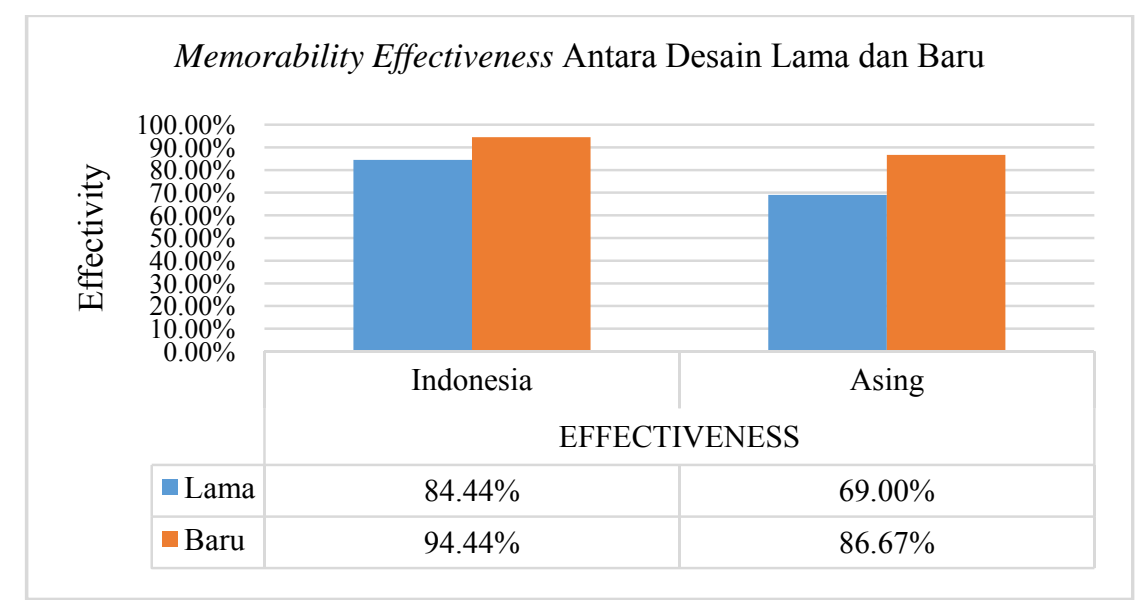

Gambar 5 Evaluasi Memorability Effectiveness Desain Lama dan Alternatif

Sesuai Gambar 5 tampak peningkatan memorability effectiveness terjadi terutama pada mahasiswa asing sebesar $18 \%$. Peningkatan ini disebabkan karena penamaan konten, peletakkan informasi yang sesuai dan urutan langkah pencarian informasi memberikan kemudahan bagi pengguna dalam mengingat task-task yang diberikan.

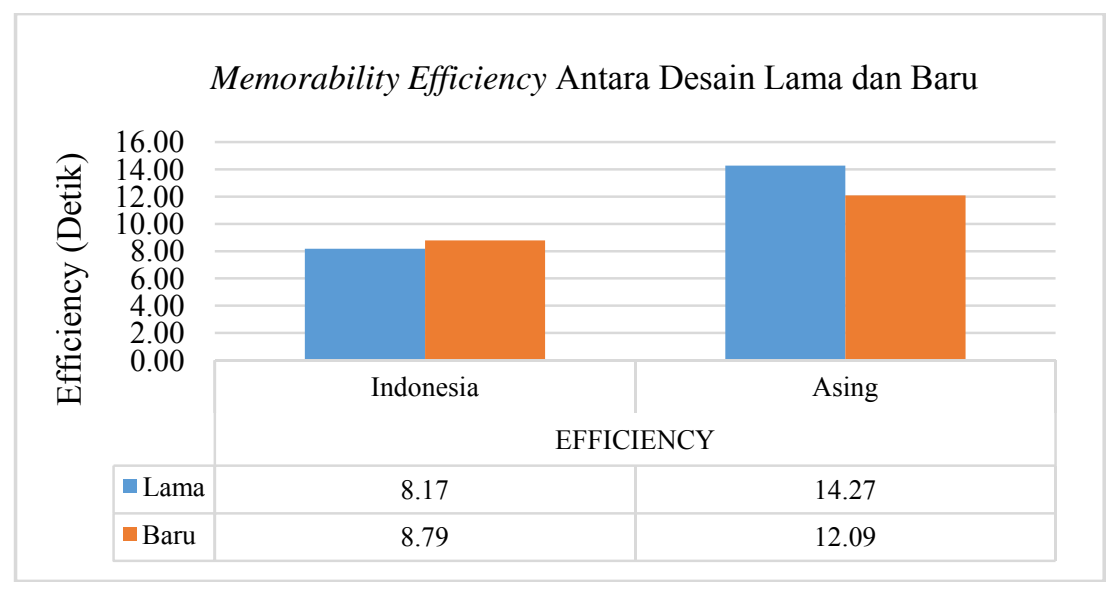

Gambar 6 Evaluasi Memorability Efficiency Desain Lama dan Alternatif 
Peningkatan memorability efficiency terjadi terutama pada mahasiswa asing karena susunan dan urutan langkah pencarian informasi memberikan kemudahan bagi pengguna dalam mengingat task-task yang diberikan. Namun, mahasiswa Indonesia mengalami penurunan memorability efficiency. Hal ini dikarenakan beberapa mahasiswa Indonesia agak sulit mengingat menu-menu ataupun konten yang ditulis dalam Bahasa asing.

\section{Satisfaction Rate Website Lama dan Baru}

Hasil pengolahan menunjukkan terjadi peningkatan satisfaction pada penngunaan website alternative seperti diberikan pada gambar 7. Namun, peningkatan drastis terjadi pada task 1, task 5 , dan error rate pengguna Indonesia karena pada saat melakukan task-task tersebut di desain lama, para pengguna mengalami kesusahan dalam menemukan informasi, dan beberapa pengguna tidak dapat menemukan informasi tersebut. Kesulitan tersebut diperoleh karena penempatan informasi yang tidak sesuai dengan kontennya dan peletakkan informasi yang tidak tepat sehingga pengguna kesulitan dalam menemukan informasi.

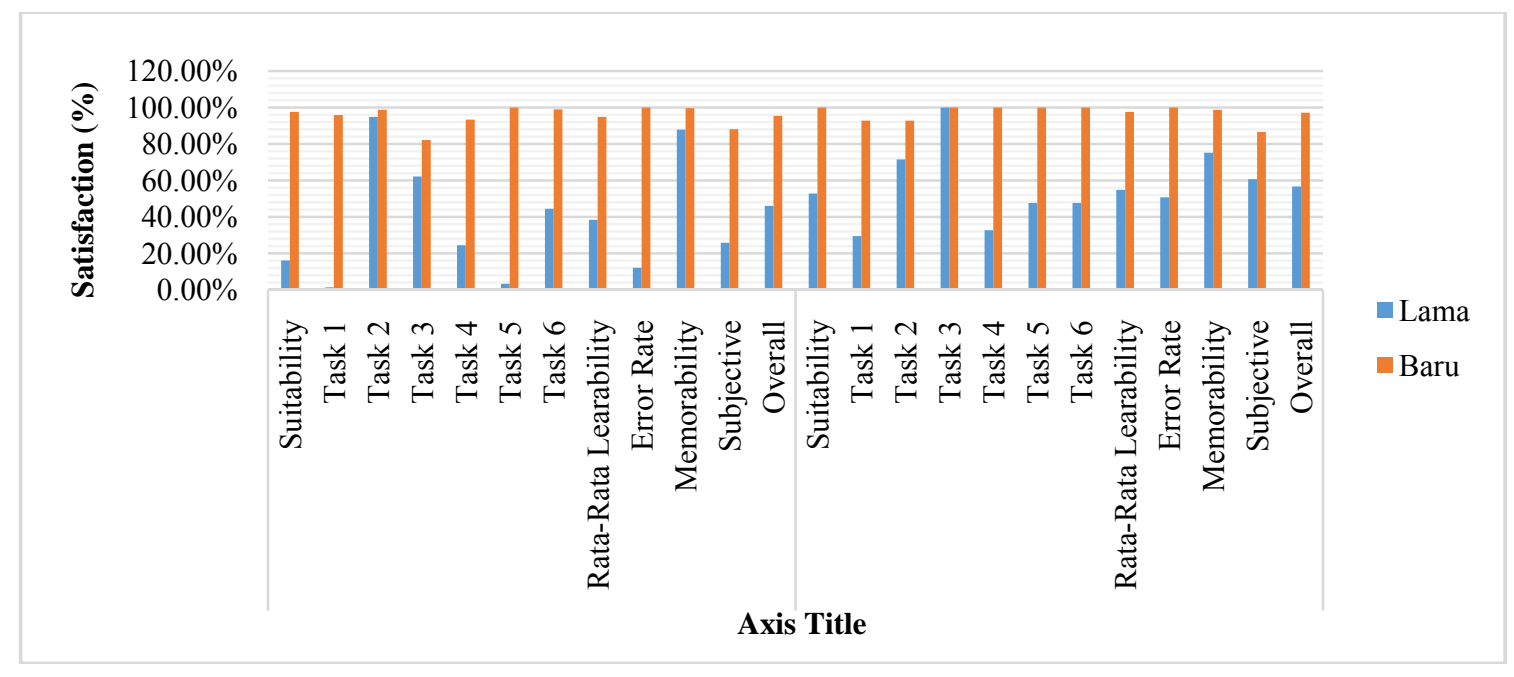

Gambar 7 Evaluasi Satisfaction Desain Lama dan Alternatif

Dumas dan Redish (1999), usability dapat digunakan untuk mengukur tingkat pengalaman pengguna ketika berinteraksi dengan produk sistem. Secara umum, usability mengacu kepada bagaimana pengguna bisa mempelajari dan menggunakan produk untuk memperoleh tujuannya dan seberapa puas pengguna tersebut terhadap penggunaannya. Usability adalah salah satu faktor kualitas sistem yang mewakili suatu jawaban dari interaksi manusia dengan teknologi. Sedangkan menurut Nielsen (1999), konsep usability testing ini diadopsi dari ilmu teknik berbicara mengenai hubungan antara manusia dengan alat (man-machine interface) dimana memungkinkan siapa saja dengan pengetahuan tertentu dapat mengoperasikan suatu perangkat teknologi dengan mudah.

Hasil pengukuran usability terhadap desain website Internasional Office UNDIP sebelum dan sesudah dilakukan redesign secara umum memberikan hasil bahwa hasil redesign dapat meningkatkan usability web. Peningkatan tersebut terjadi pada aspek efektivitas, efisiensi, memorability dan berkurangnya error rate. Berdasarkan hasil usability test yang dilakukan pada desain awal maupun alternatif menunjukkan secara umum alternative design memberikan peningkatan efektifitas, efisiensi, dan kepuasan bagi user dalam melakukan pencarian informasi sehingga alternative design dapat diterima untuk menggantikan desain awal. 
Selain metode scenario - based usability evaluation dan metode WAMMI, metode lainnya yang juga banyak dipakai adalah UCD (User Centered Design). User Centered Design merupakan proses untuk mengembangkan sistem, tujuan atau sifat-sifat, konteks dan lingkungan sistem berdasarkan pengalaman pengguna. Prinsip utama yang harus diperhatikan dalam UCD adalah fokus pada pengguna yaitu perancang sistem harus berhubungan langsung dengan pengguna atau calon pengguna, misalnya melalui interview atau survey. Tujuannya adalah untuk memahami kognisi, karakter, dan sikap pengguna. Dalam tahap ini perlu dilakukan pengambilan data, analisis dan integrasinya ke dalam informasi perancangan dari pengguna tentang karakteristik tugas, lingkungan teknis atau organisasi. Prinsip berikutnya adalah perancangan reintegrasi yaitu perancangan harus mencakup interface untuk pengguna, sistem help, panduan penggunaan, dan dukungan teknis seperti kebutuhan software dan hardware. Selain perancangan yang terintegrasi, Utomo, 2013 menyatakan bahwa untuk membangun suatu website yang baik, web designer harus memperhatikan prinsip-prinsip yang ada. Adapun prinsip-prinsip yang harus diperhatikan antara lain keseimbangan (meliputi Keseimbangan Simetris (Formal) dan Keseimbangan Asimetris (Informal), juga faktor Kontras, Konsistensi dan adanya cukup ruang kosong.

Kontras mudah dipahami yaitu dengan melihat dari dua objek yang berlainan, sehingga membuat kesan tampilan desain yang menonjol dan menarik perhatian. Pemberian kontras pada suatu objek haruslah kontras positif karena jika kontras yang diberikan negatif, objek tersebut menjadi samar-samar atau tidak terlihat, dan terserap oleh background. Konsistensi dapat membuat pengunjung merasa nyaman, karena mejelajah website lebih mudah dan tidak membingungkan. Ketika pengunjung membuka suatu halaman website yang konsisten, dia langsung tahu ke mana harus pergi dan dia tahu berada di mana. Konsistensi dapat diterapkan pada margin, tata letak, huruf, warna dan terutama navigasi. Konsistensi biasanya sangat efektif digunakan untuk membangun brand suatu individu/organisasi/perusahaan, atau atribut-atribut yang memberikan identitas dan kepribadian individu/organisasi/perusahaan. Ruang kosong biasanya disebut dengan ruang negatif, yang menggambarkan suatu ruang terbuka di antara elemen-elemen desain. Ini bisa di temukan di antara kata, paragraf, huruf dari teks, bisa juga diantara gambar dan elemen di halaman web. Ini membantu dalam mengarahkan mata pembaca dari satu titik ke titik lainnya.

\section{SIMPULAN}

Permasalahan yang dihadapi pengguna adalah penempatan menu dan konten yang kurang tepat, penamaan menu dan konten yang agak mirip dengan konten lainnya penempatan informasi yang kurang sesuai dengan kontennya, ukuran font menu yang kecil, dan tidak terdapat kotak pencarian di homepage. Serta kebutuhan-kebutuhan konten yang dibutuhkan pengguna adalah kolom scholarship, kolom exchange, kolom event, kolom immigration procedure, kolom post graduate program, agenda, dan HNMUN.

Hasil usability test yang dilakukan pada desain awal menunjukkan bahwa desain awal belum cukup efektif dan memuaskan dalam pencarian informasi. Berdasarkan hasil usability test yang dilakukan pada desain awal maupun alternatif menunjukkan secara umum alternative design memberikan peningkatan efektifitas, efisiensi, dan kepuasan user dalam melakukan pencarian informasi Sehingga desain alternative dapat diterima untuk menggantikan desain awal.

Dalam melakukan perancangan alternative design, terdapat beberapa solusi design yaitu, Pengelompokkan dan penempatan konten-konten yang sejenis di bawah header, Penempatan slide pada halaman depan, Pemberian kotak pencarian, Penghapusan agenda dan pemberian kolom informasi event, Pemisahan konten scholarship dan exchange program, Penghilangan konten-konten yang dirasa tidak berguna. Pemasangan media sosialpada bagian kanan homepage, dan Perbaikan nama konten dan informasi di dalamnya. 


\section{DAFTAR PUSTAKA}

Bevan, N. (2005). Guidelines and Standards for Web Usability. Proceedings of HCI International 2005, Lawrence Erlbaum.

Bogin, B. (2007). Human-computer interaction. New York: McGraw-Hill

Campbell, J. (2014). Web Design: Introductory. Boston: Course Technology

Chiew, T. K., Salim, S. S.(2003). WEBUSE: WEBSITE usability evaluation tool. Malaysian Journal of Computer Science, 16(1): 47- 57

Dumas, J. S., Redish, J.C. (1999). A Practical Guide to Usability Testing. Intellect, Ltd

Granić, A., Mitrović, I., Marangunić, N. (2008). Experience with Usability Testing of Web Portals. 4th Int. Conf. on Web Information Systems and Technologies. 4-7 May, 2008, Madeira, Portugal (accepted for presentation)

Hewett, T. T., Baecker, R., Card, S., Carey, T., Gasen, J., Mantei, M. (2009). ACM SIGCHI curricula for human-computer interaction: ACM

International Organization for Standardization. (1999). ISO 13407:1999Human-Centred Design Processes for Interactive Systems.

Kirakowski, J., Cierlik, B. (1998). Measuring the Usability of Web Sites. Proceeding Human Factors and Ergonomics Society. Chicago: Annual Conference.

Nielsen, J. (1999). Designing Web Usability: The Practice of Simplicity. Indianapolis: New Riders Publishing.

Pearrow, M. (2000). Web Site Usability Handbook (Internet Series). Charles River Media.

Powell, T. A. (2000). Web Design: The Complete Reference. Berkeley: McGraw-Hills

Rosinski, P., Squire, M. (2009). Strange Bedfellows: Human-Computer Interaction, Interface Design, and Composition Pedagogy. Computers and Composition, 26(3): 149-163. doi:10.1016/j.compcom.2009.05.004

Rubin, J., Chismell, D. (2010). Handbook of Usability Testing: Howto Plan, Design, and Conduct Effective Tests. Indianapolis: Wiley Publishingm, Inc

Sauro, J. (n.d.). Using a Single Usability Metric (SUM) to Compare the Usability of Competing Products.

Sklar, J. (2012). Web desing principles, the web technology series (5th edition). China: Cengage Learning.

Smith, C., Mayes, T. (1996). Telematics Applications for Education and Training: Usability Guide. Comission of the European Communities, DGXIII Project.

Umar, A., Tatari, K. K. (2008). Appropriate Web Usability Evaluation Method during Product Development.

Utomo, T. P. (2013). Modul Training Web Development. Laboratorium Informatika Dan Komputer Teknik Elektro Universitas Brawijaya 